\title{
IS THERE A ROLE FOR AN ACTIVE FISCAL STABILIZATION POLICY?
}

\author{
TORBEN M. ANDERSEN
}

\author{
CESIFO WORKING PAPER NO. 1447 \\ CAtegory 5: Fiscal Policy, Macroeconomics AND Growth
} APRIL 2005

Presented at CESifo Venice Summer Institute, Workshop on “The ReVival of Aggregate Demand Management Policies: Back to Keynes?”, July 2004

\footnotetext{
An electronic version of the paper may be downloaded

- from the SSRN website:

wWw.SSRN.com

- from the CESifo website:

www.CESifo.de
} 


\title{
IS THERE A ROLE FOR AN ACTIVE FISCAL STABILIZATION POLICY?
}

\begin{abstract}
This paper discusses the need and scope for an active fiscal stabilization policy. It is argued that the effectiveness of fiscal policy as a short run stabilizer does not depend on the long run multipliers of (balanced budget) fiscal policies. To the extent that activity can be affected by aggregate demand in the short run, there is a case for a fiscal stabilization policy in terms of temporary variations in taxes or public consumption contingent on the state of the economy. The effectiveness of fiscal policy is supported by empirical evidence. However, an appropriate policy intervention depends both on the nature of the shock and the structure of the economy. There are thus fundamental information problems in pursuing discretionary fiscal policies on top of political economy concerns, and fiscal fine-tuning is not to be recommended. Automatic stabilizers do not to the same extent suffer from these problems, but their strength is not by design but the net result of other policy considerations. Hence, there is a need to consider the structure and size of automatic stabilizers.
\end{abstract}

JEL Code: E6.

Keywords: shocks, insurance, adjustment failures, rules, discretion and fiscal policy.

\author{
Torben M. Andersen \\ Department of Economics \\ University of Aarhus \\ 8000 Aarhus $C$. \\ Denmark \\ tandersen@econ.au.dk
}

Comments and suggestions by participants at the workshop "The revival of aggregate demand management policies: Back to Keynes?" Venice, July 2004 and anonymous referees are gratefully acknowledged.. 


\section{Introduction}

The issue of the need and scope for stabilization policy remains topical in macroeconomics, and the debate has its own cycle oscillating between Keynesian and classical viewpoints. Recently views on especially monetary policy have shifted towards a greater belief in the possibility of controlling not only inflation, but also activity via an active monetary policy.

Monetary policy has a comparative advantage over fiscal policy in achieving countercyclical goals, Taylor (2000, p27)

There is a growing literature on the role of monetary policy, see e.g. Clarida, Gali and Gertler (1999), Svenson (1999) and Svensson and Woodford (2005) and for introduction and references. Somewhat surprisingly, fiscal policy has not attracted as much interest, and recent literature devotes very scant attention to fiscal stabilization policy. ${ }^{1}$ This neglect of fiscal policy is surprising for at least two reasons. First, policy makers are concerned about the role of fiscal policy and often resort to fiscal policy changes in efforts to stabilize the economy. Recent examples include the US, UK and Denmark. Secondly, many countries, notably the EMU countries, are left with fiscal policy as their only macroeconomic policy instrument. ${ }^{2}$

This paper focuses on the need and scope for fiscal stabilization policy. The outset of the paper is the recent progress in macroeconomic research on the question of the need and scope for an active stabilization policy. The main lessons are the following: Various forms of adjustment failures cause an inappropriate adjustment to shocks. To the extent policy makers can respond to these shocks in a way private markets cannot (due to contracts, adjustment costs or informational problems), there is a scope for an active stabilization policy.(for a recent analysis see e.g. Benassy (2002)).

The need and scope for fiscal policy depend critically on the way aggregate demand affects activity and employment in the short run. The main channel of fiscal policy is to affect aggregate demand, and therefore a potential for fiscal policy as a short run stabilizer depends critically on the extent to which activity in the short run is influenced by aggregate demand. Fiscal policy may also affect the supply side, and this may release additional effects to the traditional aggregate demand effects, but the supply effects will in most cases be negligible in the short run since they tend to unfold over time.

In the modern approach the gains from stabilization policy are not taken for granted. The welfare case for an active stabilization policy is explicitly linked to the ability of policy to cope with or diversify shocks in a way that differs

\footnotetext{
${ }^{1}$ In a well-known textbook like Romer (1996), fiscal stabilization policy is only mentioned in passing, and in e.g. Woodford (2003), fiscal policy is mainly discussed in relation to the requirements for price stability. The so-called New Open Economy Macroeconomics is also mainly focussed on monetary policy, see e.g. Lane (2001).

${ }^{2}$ With a fixed exchange rate and liberalized capital movements, the standard MundelFleming model would imply that fiscal policy is a very effective stabilization instrument.
} 
from what the market can accomplish under a non-interventionist policy. ${ }^{3}$.This is related to both the adjustment processes, and the structure of capital markets and imperfections in either may leave a need and scope for an active stabilization policy. To the extent stabilization policies are able to diversify or smoothen the consequences of business cycle fluctuations they may also be interpreted as a form of social insurance or risk diversification/absorption. The

The paper is organized as follows: Section 2 starts out by clarifying the mechanisms through with fiscal policy may affect activity in the short run. The choice of instruments in fiscal policy, expenditures or taxes, is further considered in section 3, and the effectiveness of the instruments is related to the structure of capital markets. The role of expectations in causing non-linearities and sign reversals in the effects of fiscal policy is discussed in section 4. Automatic stabilizers are dealt with in section 5 , and section 6 considers some political economy aspects related to the active use of fiscal policy as a stabilization instrument. Within the space allowed in this paper it is not possible to cover all aspects of fiscal policy and important omissions include: coordination of fiscal and monetary policy, debt dynamics and intergenerational distribution, and work on optimal fiscal policies in dynamic models.

\section{Fiscal policy - short run vs. long run effects}

It is useful to start by making a little detour into recent developments in macroeconomics to identify potential reasons why fiscal stabilization policy has not been in focus. The quest for explicit microfoundation of macromodels has led to substantial progress in understanding both the basic mechanisms causing business cycle fluctuations and why they may be associated with inefficiencies and welfare losses. Moreover it has led to a better understanding of the channels through which policy intervention may work. However, in a large part of the literature the level of activity is supply determined. Accordingly the transmission mechanism of fiscal policy comes to run via supply incentives. In the often considered closed economy model with "one good and no capital", this implies that labour supply takes centre stage. An expansion of public consumption leads to tax increases and the effects on output depend on how labour supply responds to the tax increase. ${ }^{4}$ In a well-known paper by Dixon (1987), fiscal policy is considered in a setting with imperfectly competitive product markets and lump sum financing of public consumption implying that only the income effect is operative in affecting labour supply (see also Mankiw (1988), Dixon and Lawler (1996)). With lump sum financing, higher public consumption and thus taxation cause labour supply to increase, and therefore the fiscal multiplier

\footnotetext{
${ }^{3}$ Musgrave's famous distinction between the allocative, distributional and stabilization effects of policy teaches us to distinguish the three. However, modern literature has shown that it is not meaningful to make such a distinction. When cast in an explicit microfounded model, the role for stabilization relies on adjustment failures and failures in risk diversification, and both have allocative and distributional consequences and vice versa.

${ }^{4}$ In models with imperfectly competitive labour markets, the effects depend on how taxation influences wage formation, see e.g. Pissarides (1998).
} 
is positive. Baxter and King (1993) arrived at similar conclusions in an RBC type model. Allowing for distortionary taxation, it follows that the effect of a tax increase on labour supply depends on the balance between income and substitution effect. ${ }^{5}$ The net effect of a fiscal expansion on activity is therefore in general ambiguously signed ${ }^{6}$ when assessed from this supply side perspective.

This line of approach has been extended by considering the incentive effects of taxation on savings, capital formation, wage formation etc. (see e.g. Baxter and King (1993) and Alesina et. al. (2002)). However, a fundamental question is whether it is appropriate to consider business cycle fluctuations as movement up and down the labour supply curve and leaving no role for aggregate demand. It is well known that models with this approach have difficulties explaining stylized facts concerning the labour market (Stadler (1994)) and in generating plausible business cycles (Cogley and Mason (1995)).

A volumniuous literature considers the role of failures in adjustment of prices and wages. These models usually assume that activity in the short run (period in which adjustment failures apply) is determined by demand. However, the usual procedure is to let aggregate demand be determined by aggregate nominal demand where the latter is determined by monetary policy (for a recent example see Woodford (2003)). This feature arises in a large class of models where a money demand relation is derived from a "money in utility" approach, cash in advance constraints or an overlapping generations structure. Hence, these models are demand driven in the short run, but by nominal and not real demand. An indication why this approach is problematic is that models with price stickiness have difficulties matching observed comovements between, say, consumption and activity. In the data, correlation between the two is high (usually above 0.8 ), while in a calibrated RBC model with nominal stickiness it is very low (about 0.2), see e.g. Hairualt and Portier (1993). ${ }^{7}$ This suggests that both the approach to determination of activity in the short run and consumption (intertemporal consumption model) may be questioned.

For the subsequent discussion of fiscal policy it is therefore important to bring out the demand channels through which fiscal policy can affect aggregate

\footnotetext{
${ }^{5}$ Consider a household maximizing a standard utility function $U(C, 1-L)$ subject to $C=$ $(1-\tau) \frac{W}{P} L+I$, where $C$ is consumption, $L$ work, $\frac{W}{P}$ the real wage, $\tau$ the tax rate, and $I$ other source of income. Solving for labour supply it follows that $\operatorname{sign}\left(\frac{\partial L^{s}}{\partial(1-\tau) \frac{W}{P}}\right)=$ sign $\left[U_{C, C}^{\prime \prime}+U_{c}^{\prime}+U_{C, 1-L}^{\prime \prime}\right] \lessgtr 0$ under standard sign assumptions.

${ }^{6}$ There is still some confusion about this in the literature. Often utility functions that impose particular assumptions on the income and substitution effects are chosen . For instance the popular Cobb-Douglas specification implies that the income and substitution effects balance each other, leaving labour supply unaffected by an income tax (if labour income is the only source of income).

${ }^{7}$ It is well known that the standard RBC model replicates the movements of aggregate demand movements quite well, not least private consumption, cf. e.g. Prescott (1987). This may seem surprising since the model relies on the intertemporal consumption model, which in other respects is known to have empirical problems. The key to reconciling these two findings may lie in the fact that the RBC model is calibrated with very persistent real shocks. In this case, the intertemporal consumption model implies a marginal propensity to consume close
} to one, cf. section 3 . 
activity.

\subsection{Adjustment failures and fiscal stabilization policy}

A traditional reason for aggregate demand to play a role for activity is the presence of various adjustment failures. As noted above a large literature has explored this in a setting where aggregate demand is determined by nominal demand (the money supply). However, considering a setting in which monetary policy determines the nominal interest rate implies that aggregate real demand as in the traditional textbook model come to determine activity in the short run (the time frame within which adjustment failures prevail). A simple example is an intertemporal model for a closed economy with nominal wage contracts. In this setting it is straightforward that the short run aggregate supply curve is increasing in the aggregate price level (up to a capacity constraint), while the aggregate demand curve is downward sloping since a higher price affects the expected real rate of interest and therefore aggregate demand, cf. Appendix A for an illustrative model. Changes in aggregate demand influence activity and a fiscal expansion will therefore be able to induce higher activity, see also Benassy (2002)

This approach leaves several important lessons concerning the role of fiscal stabilization policy. First, the short run effect of a fiscal expansion is independent of the factors determining the long run effects of fiscal policy on activity, i.e. there is a case for a traditional countercyclical stabilization policy even if the long run fiscal multiplier may be negative. Second, the room for fiscal policy is shock dependent. Third, the room for fiscal stabilization is generated by the fact that activity is sub-optimal in the short run due to adjustment failures. There is thus a welfare case for an active policy to the extent that it can counteract the effects of shocks in way in which the market is not able to do so. Finally, but crucially, the stabilization policy thus has to be temporary (being defined as the time span for which adjustment failures cause activity to be suboptimal low) and adapted to both the shock and the adjustment process in the economy.

\subsection{Composition of demand}

The preceding analysis was based on adjustment failures for wages (or prices) as a way to allow activity to be demand determined in the short run. There is another important route through which fiscal policy can affect activity in the short run even in the absence of adjustment failures for wages and prices. This arises via the effect a change in public consumption may have on the composition of demand. In aggregate models this is most easily seen ${ }^{8}$ in the context of an open economy model with a distinction between tradeable and non-tradeable commodities. Domestic demand plays no role for determination of activity in the former market, but does in the latter. If public consumption

\footnotetext{
${ }^{8}$ See Dixon and Rankin (1994) for a discussion of the role of the composition of demand in models with imperfectly competitive markets.
} 
is more directed towards non-tradeables than tradeables, ${ }^{9}$ it follows that an expansion of public consumption (even under a balanced budget) will change the composition of demand, and therefore in general the level of activity (see e.g. Marston (1985)). Andersen (2004) shows in an intertemporal model for an open economy under the product market structure stipulated above that a temporary increase in public consumption will boost current activity (and lower future activity) independently of the sign of the long run multiplier. This applies irrespective of type of shock and whether lump sum or distortionary taxes are used (Andersen and Holden (2002)).

\subsection{What should be stabilized?}

The traditional literature has taken the policy objective of stabilizing output as given $^{10}$. More recent approaches building on an explicit microfoundation make it possible to assess the welfare implications of fluctuations,. see e.g. Obstfeld and Rogoff (2002), Woodford (2003), Andersen and Spange (2004). This naturally leads to an explicit consideration of the consequences of risk and the possibilities of diversifying them via e.g. stabilization policy. Accordingly stabilization policy can be interpreted as a form of (implicit) insurance in the sense that it modifies the consequences of various shocks, i.e. shock diversification. Maximizing of welfare is therefore not necessarily tantamount to minimization of say output variability.

This naturally raises the question of the welfare costs of business and thereby also the potential gains from an active stabilization policy. Lucas (1987) questioned whether the welfare costs of business cycles are significant, and suggested that they are not. By implication the potential gains from an active stabilization policy are bound to be small. Recent work has challenged this conclusion see e.g. Gali, Gertler, and Lopez-Salido (2003) and Storesletten, Telmer and Yaron (2004). In particular market imperfections including capital market structures as well as heterogeneity among agents are crucial for the size of the welfare effects of business cycle fluctuations. Allowing for heterogeneity and non-diversifiable risk among agents imply that the welfare costs of business cycle fluctuations may be non-trivial. This is an important area for future research.

Finally, the importance of stabilization policy is also supported by a revealed preference argument. The fact that so many commentators, institutions and policy-makers are concerned about business cycle fluctuations and stabilization policy suggests that this must be important. In this respect it is interesting to note that it is very hard to find comments on business cycle developments that do not focus on how aggregate demand is evolving.

\footnotetext{
${ }^{9}$ Which is empirically the case since most public consumption is wage expenses, which by definition are directed towards non-tradeables markets (national labour markets).

${ }^{10}$ The issue of stabilization is here distinguished for the question of lowering unemployment. The latter involves structural issues causing a persistently inefficiently low level of activity.
} 


\section{Fiscal instruments: expenditures and taxes}

An important question is which fiscal instruments to use. In a short run perspective, the question is to identify the most effective instrument in influencing aggregate demand: is it expenditure changes or tax changes? The answer turns out to depend critically on the structure of capital markets.

\subsection{Ricardian equivalence}

An issue which often comes up is whether Ricardian equivalence would eliminate the scope for a fiscal stabilization policy. To see that this is not the case consider the following deterministic setting. Capital markets are perfect (in the sense of offering a known real rate of return $r$ ), and households have an infinite horizon. A combination of assumptions that hardly can be said to have a Keynesian bias. Let the household utility function be defined over utility derived from consumption $C$ in all future periods,

$$
\sum_{i=0}^{\infty} \beta^{i} U\left(C_{t+i}\right) \quad 0<\beta \leq 1
$$

where $\beta$ is the subjective discount factor. The intertemporal budget constraint reads

$$
\sum_{i=0}^{\infty}\left(\frac{1}{1+r}\right)^{i} C_{t+i}=\sum_{i=0}^{\infty}\left(\frac{1}{1+r}\right)^{i}\left(Y_{t+i}-T_{t+i}\right)
$$

where $Y_{t+i}$ denotes income, $T_{t+i}$ denotes lump sum taxes paid in period $t+i$ and $r$ is the market rate of interest (assumed constant over time for simplicity). Assuming for the sake of argument that the objective and subjective rates of time preference are the same $\left(\frac{1}{1+r}=\beta\right)$, it follows that the optimal consumption decision implies

$$
\begin{aligned}
C_{t+i} & =C=\frac{r}{1+r}\left[\sum_{i=0}^{\infty}\left(\frac{1}{1+r}\right)^{i}\left(Y_{t+i}-T_{t+i}\right)\right] \\
& =\frac{r}{1+r}\left[\sum_{i=0}^{\infty}\left(\frac{1}{1+r}\right)^{i} Y_{t+i}-\sum_{i=0}^{\infty}\left(\frac{1}{1+r}\right)^{i} G_{t+i}\right]
\end{aligned}
$$

where it has been used that the public sector budget constraint reads

$$
\sum_{i=0}^{\infty}\left(\frac{1}{1+r}\right)^{i} G_{t+i}=\sum_{i=0}^{\infty}\left(\frac{1}{1+r}\right)^{i} T_{t+i}
$$


where $G_{t+i}$ is public consumption in period $t+i$. The consumption function (1) gives consumption according to the standard intertemporal consumption model, where there is a desire to smooth consumption, which therefore is determined by the present value of disposable income.

For a given consumption profile, a temporal shifting of taxes (e.g. lowering current taxes and increasing future taxes) would not affect private consumption and thus aggregate demand. A change in public consumption would however affect private consumption. If the aim is to increase current aggregate demand $(C+G)$, it follows straightforward that temporary changes in public consumption would be fairly effective since the effect on private consumption (for exogenous income) is

$$
\left.\frac{\partial C_{t}}{\partial G_{t}}\right|_{\text {temporary }}=-\frac{r}{1+r}>-1
$$

Crowding out depends on the discount rate, and if $r \in[0.02,0.04]$, it follows that $\left.\frac{\partial C_{t}}{\partial G_{t}}\right|_{\text {temporary }} \in[-0.02,-0.05]$, and $\left.\frac{\partial C_{t}+G_{t}}{\partial G_{t}}\right|_{\text {temporary }} \in[0.95,0.98]$, i.e. the (intertemporally balanced budget) multiplier is close to one ${ }^{11}$. Note that this holds under rational expectations. Under Ricardian Equivalence an increase in public consumption crowds out private consumption, but if the former is temporary, the crowding out effect is very small. The reason is that households aim at smoothing the consumption profile, and therefore the increase in taxation needed to finance the temporary expansion in public consumption is spread over time. Ricardian equivalence does not make a temporary increase in public consumption an ineffective instrument to increase total demand $(C+G)$. Actually, the longer the horizon of the household, the stronger the diversification effect as captured here by assuming an infinite horizon. It is important that the change is temporary (and is perceived as such). For a fully permanent change in public consumption, crowding out will be complete $\left(\left.\frac{\partial C_{t}}{\partial G_{t}}\right|_{\text {permanent }}=-1\right)$, and aggregate demand would be unaffected.

\subsection{Capital market imperfections}

Under Ricardian equivalence temporary changes in taxes have no (or a very small) effect on private consumption and thus aggregate demand. This results depends critically on the assumption that there is a given interest rate at which the household can transfer resources back and forth over time (no liquidity constraints). In combination with the assumption of infinitely lived households, this delivers very strong, but also debatable results like the irrelevance of the public sector budget position. Some of the basic reasons why business cycles pose a problem are related to capital market imperfections, and it is therefore natural to consider their role in more detail.

\section{Liquidity constraints}

\footnotetext{
${ }^{11}$ Even allowing for distortionary taxation would not change the thrust of this argument, since the permanent increase in the tax rate would be small.
} 
A crucial assumption underlying the intertemporal consumption model is that agents can borrow based on expected future labour income. Borrowing with collateral in future labour income raises fundamental incentive problems involving moral hazard and adverse selection. There are thus good reasons why there are restricted possibilities for moving consumption possibilities based on expected future labour income to the present.

A limiting form of capital market imperfection arises when households are liquidity constrained, that is, those households that like to borrow to increase current consumption are unable to do so. Following this line of thought one may think of aggregate private consumption as being determined as (see Jappelli and Pagano (1989), Campell and Mankiw (1991))

$$
C_{t}=\left.\pi_{t} C_{t}\right|_{\text {constrained }}+\left.\left(1-\pi_{t}\right) C_{t}\right|_{\text {unconstrained }}
$$

where $\pi$ is the fraction of liquidity constrained consumers ("hand to mouth" consumers) with consumption $\left.C\right|_{\text {constrained }}$ being determined by disposable income, while the unconstrained households have consumption given as $\left.C\right|_{\text {unconstrained }}$ determined by the standard intertemporal consumption model. Consider now the effect on private consumption of a temporary tax (lump sum) reduction, we find

$$
\frac{\partial C_{t}}{\partial T_{t}}=\pi_{t} \frac{\left.\partial C_{t}\right|_{\text {constrained }}}{\partial T_{t}}+\left(1-\pi_{t}\right) \frac{\left.\partial_{t} C\right|_{\text {unconstrained }}}{\partial T_{t}}
$$

If $\frac{\left.\partial C_{t}\right|_{\text {constrained }}}{\partial T_{t}} \simeq-1$ and $\frac{\left.\partial C_{t}\right|_{\text {unconstrained }}}{\partial T_{t}} \simeq 0$ it follows that $\frac{\partial C_{t}}{\partial T_{t}} \simeq-\pi_{t}$. The marginal consumption effect is (approximately) given by the fraction of liquidity constrained households. In the case of large tax changes, note that the fraction of liquidity constrained consumers may also change.

Note that it in general may be more natural to think of credit market imperfections as being asymmetric. Agents wanting to postpone consumption possibilities can do so more easily than agents wanting to move consumption forward to the present. This implies that the consequences of a tax increase may differ from the effect of a tax increase.

The importance of liquidity constraints has been addressed in many empirical studies, and in a recent analysis involving 20 OECD countries, Sarantis and Stewart (2003) find that the average estimate of $\pi$ is 0.7 (minimum value 0.33 and maximum value 0.99 ), suggesting that liquidity constraints play a nontrivial role. It follows that a temporary tax reduction could have a significant effect on private consumption. This relates also to the voluminous literature testing for Ricardian Equivalence, and it is generally rejected (for a recent survey and references see Ricciuti (2003)).

Microevidence on this issue is found in studies testing whether agents are able to diversify consumption risk as would be implied by complete capital markets (see e.g. Dynarski et.al. (1997), Gruber (1997), Knieser and Ziliak (2002)). Such diversification of consumption risk is in general clearly rejected, indicating that capital markets are incomplete, and changes in disposable income are found to have a significant effect on consumption.

\section{Precautionary savings}


The intertemporal consumption model is usually presented in a form with perfect foresight or where certainty equivalence holds. However, when capital markets are incomplete and labour income non-diversifiable there is a precautionary motive for saving, i.e. to ensure consumption possibilities also in periods with low income. This may be interpreted as "buffer stock" saving behaviour, cf.. Carroll (2001) in the sense that agents will target a given level of "cashon-hand" (relative to permanent income) given by financial wealth and current income. If "cash-on-hand" is below target, agents will try to re-build the stock, and if it is above, it can be depleted. An important implication is that the marginal propensity to consume out of "cash-on-hand" is much above that predicted by the intertemporal consumption model. Carroll (2001) presents numerical illustrations for a population with a given distribution of wealth and income risk and finds an average marginal propensity to consume of $1 / 3$. Accordingly, a temporary tax reduction would also here have a significant effect on private consumption.

Note that agents under precautionary savings behave very much like "credit constrained" individuals facing liquidity constraints. For example, agents with low "cash-on-hand" will tend to spend their income and have a marginal propensity to consume equal to one.

\subsection{Empirical evidence}

For the design of stabilization policy it is important to have a quantitative assessment of the effectiveness by which changes in public expenditures or taxes can affect activity. While there is a voluminous empirical literature on fiscal policy, it is important in interpreting the results to distinguish between the effects of stabilization policy and the effects of a given change in fiscal polic ${ }^{12}$. The former is defined in relation to a particular business cycle situation, whereas there can be many other reasons for changes in public consumption or taxes. Evidence on the latter may therefore not be an appropriate yardstick for evaluating the scope for the former. In the same vein observe that assessing discretionary changes in fiscal policy by changes in the structural budget deficit is also problematic both because such changes can be driven by other causes than fiscal policy, ${ }^{13}$ and because the activity effects of fiscal policy changes are not well approximated by their effects on the public budget.

Fiscal multipliers can be assessed from various macroeconometric models. In a recent survey, Hemming et.. al. (2002) conclude that although the range of short-run multipliers is wide, the expenditure multipliers tend to be in the range 0.6 to 1.4 (meaning that a one percentage increase in government consumption will increase GDP by 0.6 to $1.4 \%$ ), and the tax multipliers in the range 0.3 to 0.8. Moreover, the multipliers are significantly smaller in the long run than in

\footnotetext{
${ }^{12}$ An example is VAR-analysis where impulse response functions are generated to innovations in fiscal policy. These innovations are by construction unrelated to the state of the economy, and therefore they do not capture stabilization policies which by definition are motivated by a particuar business cycle situation.

${ }^{13}$ For instance changes in labour market structures.
} 
the short run.

Analyses based on smaller structural models have also been used to assess the effects of fiscal policy. ${ }^{14}$ One recent example is Alesina et. al. (2002), which focusses on the possible crowding out effects of fiscal policy running via wages, profits and investment. Two interesting conclusions come out of this analysis. The short run multipliers always have the conventional signs, although the long run multipliers may display non-Keynesian signs. This stresses the point made above that the scope for short run stabilization cannot be asserted by evaluating long run multipliers. Second, the multipliers - both in the short and long run depend critically on the specific fiscal instrument. This also underlines that the fiscal stance is only poorly approximated by the structural balance.

Estimations of fiscal reaction functions can be used to asses whether fiscal policy has been countercyclical and contributing to stabilization, see e.g. Auerbach (2003) and Gali and Perotti (2003). Both analyses find that the fiscal policy reactions have been countercyclical, and in this way they can be said to have contributed to stabilization ${ }^{15}$.

Finally, the importance of changes in fiscal policy for aggregate activity can also be assessed by the so-called VAR approach in which the dynamic response to shocks to spending and taxes can be traced. In a recent analysis, Blanchard and Perotti (2002) find that spending shocks have positive and tax shocks have negative output effects, and that the effects are fairly persistent.

When fiscal policy is effective, there is also a risk that it may be "misused" in the sense of contributing to output destabilization. This may arise either because fiscal policy interventions are badly designed and timed relative to the business cycle situation, or because fiscal policy is changed for reasons unrelated to the business cycle (destabilizing effects may be perceived or not). Fatás and Mihov (2003) thus find that countries with the most volatile public consumption also tend to have the most volatile business cycles. Whether this supports a case against fiscal discretion is an open question as long as the reasons for changes in fiscal policy have not been identified.

\section{Expectations}

While there is an extensive literature on the role of expectations for the effects of monetary policy, there has been less focus on how expectation formation influences fiscal policy multipliers. However, expectations about future fiscal policy may have important effects if agents are forward looking (rational expectations).

It is clear from the preceding discussion that it is crucial whether a fiscal policy intervention is perceived as temporary. If changes in fiscal policy intended to be temporary are perceived by the private sector as permanent then the

\footnotetext{
${ }^{14}$ Finally, the effects of fiscal policy have also been evaluated in calibrated models, see e.g. Baxter and King (1993).

${ }^{15}$ Lane (2003) presents empirical evidence interpreted as showing the influence of political economy factors for the cyclical properties of fiscal policy.
} 
stabilization effort will be muted or may be even overturned. To see this, return to the standard intertemporal consumption model of section 3.1. If there is a temporary change in public consumption, the effect on private consumption is $\left.\frac{\partial C_{t}}{\partial G_{t}}\right|_{\text {temporary }}=-\frac{r}{1+r}$; if the tax change is perceived to be permanent, the effect is $\left.\frac{\partial C_{t}}{\partial G_{t}}\right|_{\text {permanent }}=-1$, cf.. above.

It follows that the crowding out effect depends critically on expectations. A policy intervention intended to be temporary, but perceived as persistent will be much less effective than one for which it is credible that it is temporary. Accordingly, expectations matter as much for fiscal policy as for monetary policy.

An important point is that expectations of future fiscal policy may depend on the present fiscal stance, e.g. the current expenditure level or the current debt level. This is so since these levels may signal something about future fiscal policy, and thereby influence expectations formation. This link to expectations may cause non-linearities or state dependencies in the effects of fiscal policy, that is, the effects of fiscal policy intervention may depend critically on the initial policy situation. To see how this can arise, consider first a case where Ricardian Equivalence holds implying that the expected present value of public consumption is influencing private consumption, cf.. (1). Assume that public consumption follows a stochastic process with upward drift, and that it fluctuates within an upper and lower bound (Bertola and Drazen (1993)). The interpretation is that whenever public consumption reaches a high level (the upper bound) there is a consolidation (to ensure sustainability) lowering public consumption (to the lower bound) upon which the process starts again. Under these assumptions, the expected present value of public consumption is dependent on the current level of public consumption. If the current level is low, increases are expected, while if the current level is close to the upper level, a consolidation is approaching. Hence, for a low level of public consumption, the expected present value of public consumption is higher than its current level, and vice versa for a high level close to the upper bound. At low levels of public consumption, an expansion in public consumption will thus increase the expected present value of government consumption, and this will lower private consumption (though less than one-to-one), i.e. there is crowding out of private consumption. At a high level of public consumption, an increase in public consumption may lower the expected present value of future public consumption since the point of consolidation is coming closer, and therefore private consumption may increase, i.e. there is a crowding in effect. The point is that the fiscal multiplier depends on the level of public consumption because the latter influences the expected present value of future public consumption and thus how private consumption is adjusted.

A similar mechanism may arise in the absence of Ricardian equivalence. Assume the profile for public consumption to be given, and consider the effects of a change in tax policy, e.g. lowering taxes today would increase the deficit and call for higher taxes in the future. Sutherland (1997) considers this issue in a so-called "perpetual youth" model in which private households discount the future more (due to the probability of dying) than the government. The 
government may lower taxes and create deficits, but there is an upper level of debt which is feasible (given sustainability), and if this debt level is reached, a consolidation in the form of tax increases takes place. Consider the effects of a tax reduction causing a budget deficit and rising debt. If the initial debt level is low, the deficit would have only a small effect on expected future taxes, and therefore private consumption would increase. However, at a high debt level a further deficit would make the point of consolidation and thus tax increases approaching, and therefore private consumption may fall. Both the size and sign of how taxes affect private consumption are thus dependent on the level of debt.

An intriguing question is whether expectations may reverse the signs of fiscal multipliers such that a fiscal consolidation may turn out to be expansionary. An interesting possibility for many countries facing the twin problems of systematic public deficits and high unemployment. The basic idea for an "expansionary consolidation" is that a change in current fiscal policy signals something about future policies, cf.. above, which in turn may affect expectations and therefore private decision making like consumption and investment. The premise is that activity in the short run is determined by aggregate demand, and the question is whether a contraction of, say, public consumption or a tax increase may expand private demand. In the case considered by Sutherland (1997), this arises straightforward at a high debt level. In the Bertola and Drazen (1993) set-up, it arises in the case of an unanticipated consolidation (before the upper bound is reached), in which case there is an unanticipated fall in the expected present value of taxes, and therefore private consumption increases. It is worth stressing that an expansion in private demand following e.g. a contraction of public demand is a necessary, but not sufficient condition for a fiscal contraction to be expansionary. An expansion requires that the net effect on aggregate demand is positive.

There has been an extensive debate on the possibility of encountering expansionary fiscal contractions, various case studies have been undertaken, and econometric studies of the issue have been performed (see e.g. Giudice et. al. (2003)). This is not the place for a detailed discussion of this literature, but two points are worth stressing. First, it is unclear in the case studies and in the econometric work whether the effects of fiscal policy changes have been adequately separated from other changes in the same periods. ${ }^{16}$ Second, even leaving this aside, the econometric evidence sends an unclear message. Fiscal contractions may or may not be expansionary, but as long as we don't know the precise conditions underlying whether one or the other holds, this is of little use in policy recommendations.

To sum up, expectation effects may imply that fiscal policy effects become more or less Keynesian, ${ }^{17}$ and hence it is not possible to make unambiguous

\footnotetext{
${ }^{16}$ As an example the fiscal consolidation in Denmark in the early 1980s is often mentioned as a prime example of an expansionary fiscal contraction. However, it coincided with a tight income policy, a shift in exchange rate policy and liberalization of financial markets.

${ }^{17}$ Van Haan (2004) shows how fiscal policy can affect whether the economy approaches a low or high unemployment equilibrium in the presence of multiple equilibria.
} 
conclusions on how expectation formation influences fiscal policy. Expectation formation has implications for implementation of fiscal policy, cf.. below, and one lesson from the empirical evidence is that expectations matter, and credibility problem make it is easier to have them working against you than for you.

\section{$5 \quad$ Fiscal Rules - Automatic stabilizers}

The previous discussion has dealt with discretionary changes in fiscal policy where policy intervention is based on an assessment of the current business cycle situation. Therefore problems of information and implementation (including political economy aspects) are important, cf.. below. This is to a lesser extent the case for the part of fiscal stabilization policy which is rule based due to automatic reactions in public consumption and in particular taxation when the business cycle situation changes. This is a consequence of the way in which social, labour and tax policies are designed, since this in general introduces state contingencies in the case of entitlements in the case of a lost job, or tax payment contingent on income etc. In a macrocontext these reaction are known as automatic stabilizers or the automatic budget response.

In a setting with capital market imperfections it is possible to interpret automatic stabilizers as an implicit insurance mechanism, since such a policy effectively introduces contingencies in e.g. taxes, expenditures and thus in general in the budget, which in turn affects the allocation of risk across agents and time. This interpretation is interesting because it brings forth the relationship between stabilization policy and the welfare state. ${ }^{18}$ Market failures in the provision of insurance are particularly important in a discussion of the welfare state, since many public sector activities can be interpreted as social insurance, that is, the public sector offers services and transfers if various contingencies are realized through life. Hence, the arrangements which in an ex post sense may be interpreted as serving a redistributive role will often in an ex ante sense have an insurance function. Modern economic theory has shown that this applies widely to public services, transfers and taxation (see e.g. Barr (2004)).

To illustrate the basic risk sharing aspects of fiscal rules consider the following stylized case. There is an exogenous, but stochastic output level $Y=\bar{Y}+\varepsilon$ $(\bar{Y}$ can be interpreted as steady state output, and $\varepsilon$ a stochastic innovation where $E \varepsilon=0)$, that can be used for private $(C)$ or public $(G)$ consumption $(Y=C+G)$. Assume that public consumption is given as $G=\bar{G}+\kappa \varepsilon$, where $\kappa$ is the state contingency or "automatic stabilizer" in fiscal policy. Suppose that the government is utilitarian and chooses $\bar{G}$ and $\kappa$ to maximize

$$
E[U(C)+V(G)] U^{\prime}>0, U^{\prime \prime}<0, V^{\prime}>0, V^{\prime \prime}<0
$$

\footnotetext{
${ }^{18}$ The interpretation in terms of social insurance also raises problems for the usual approach of separating stabilization policy from the aim to correct for market failures and to pursue redistributive policies (the Musgrave distinction). Market failures provide a rationale for stabilization policy, and such policies provide insurance which can be hard to distinguish from redistribution
} 
subject to $\bar{Y}+\varepsilon=C+\bar{G}+\kappa \varepsilon$. Note that the utility of private and public consumption is assumed to be given by different utility functions, but they both display risk aversion. Moreover in this static setting it is impossible to distinguish between contingencies in public consumption and taxes, since the budget by definition has to be balanced. It follows straightforward that it is optimal for the policy maker to choose a $\kappa>0$. Since private consumption is given as

$$
C=\bar{Y}-\bar{G}+(1-\kappa) \varepsilon
$$

introducing a state contingency in public consumption $(\kappa>0)$ reduces the variance of private consumption $\left(\frac{\partial \operatorname{Var}(c)}{\partial \kappa}<0\right)$ and setting $\kappa>0$ is optimal since it diversifies risk between public and private consumption. Effectively fiscal policy works as a shock absorber, some of the (non-diversifiable) risk is absorbed by the public sector, and therefore private consumption becomes less volatile. One could also say that the cost of a stabilization policy reducing private consumption variability is measured in terms of the increased variability in public consumption. A further implication is that the optimal policy has a procyclical variation in taxation, in periods with high income more resources are transferred to the public sector, and given the static set-up, public consumption therefore increases. This illustrative static case brings forth that there are some scope for risk diversification via fiscal policy even under a balanced budget, i.e. diversification of risk does not require that the policy can run non-balanced budgets.

In an intertemporal set-up the scope for risk diversification by automatic stabilizers becomes stronger since transitory shocks can be diversified over time. If the conditions for Ricardian Equivalence do not hold, ${ }^{19}$ the temporal allocation of tax payments matters. Accordingly it may become possible to diversify the income risk faced by households without necessarily having to transfer the risk into public sector activities to which there is also risk aversion. To see this, assume that agents are liquidity constrained such that private consumption is determined by disposable income (this could arise if agents are liquidity constrained, cf.. section 3 or in an overlapping generations model, cf.. Andersen and Dogonowski (2002)). Assume that income $Y_{i}$ is stochastic (with given mean and variance) and that the tax rate for an income level $Y_{i}$ is $\tau\left(Y_{i}\right) \geq 0$. It follows straightforward that disposable income equals $\left(1-\tau\left(Y_{i}\right)\right) Y_{i}$, and clearly the disposable income becomes less sensitive to variations in gross income, i.e.

$$
\frac{\partial\left(1-\tau\left(Y_{i}\right)\right) Y_{i}}{\partial Y_{i}}=1-\tau\left(Y_{i}\right)\left[1+\eta\left(Y_{i}\right)\right]<1 \quad \text { if } \quad \tau\left(Y_{i}\right)\left[1+\eta\left(Y_{i}\right)\right]>0
$$

where $\eta\left(Y_{i}\right)=\frac{\partial \tau\left(Y_{i}\right)}{\partial Y_{i}} \frac{Y_{i}}{\tau\left(Y_{i}\right)}$ is the elasticity of the tax rate wrt. income, i.e. it measures the degree of progression in the tax system.

\footnotetext{
${ }^{19}$ Note that sufficient conditions for this buffer or insurance function via the public budget to have beneficial welfare effects are that agents have finite horizons (as opposed to the public sector) or can access the capital market on better terms (a lower rate of interest).
} 
It is seen that the tax system implies ${ }^{20}$ that there is less variability in disposable income than in gross income.

$$
\operatorname{Var}\left[\left(1-\tau\left(Y_{i}\right)\right) Y_{i}\right]<\operatorname{Var}\left[Y_{i}\right]
$$

Note that a proportional taxation scheme $\left(\eta\left(Y_{i}\right)=0\right)$ is sufficient to provide risk diversification, but a progressive taxation scheme $\left(\eta\left(Y_{i}\right)>0\right)$ makes disposable income even more stable. If taxes are contingent on the state of nature - as any income tax scheme will be - then there is an insurance element involved (first pointed out by Domar and Musgrave (1944)) that entails a transfer from the lucky (those with a high income) to the unlucky (those with a low income). If agents are risk averse and capital markets incomplete, it follows that policies which can diversify risk may potentially improve welfare.

The index $i$ can be interpreted as running over different individuals, in which case the taxation scheme provides insurance to individual or idiosyncratic shocks $^{21}$ (Varian (1980), Sinn (1995)). It can also be interpreted as a time index in which case there is insurance over time to aggregate shocks (Gordon and Varian (1988), Andersen and Dogonowski (2002)).

To interpret the risk diversification achieved in the case of aggregate shocks, note that the public budget plays a key role. When Ricardian equivalence does not hold, the budget provides a buffer or insurance function via the basic mechanism that it can be used to smooth the consequences of aggregate shocks over time. In this way it can offer an "implicit" diversification possibility, which can be difficult to establish in private markets $^{22}$. To see this, consider the following case. Output is stochastic, but exogenous, and there is a given level of public consumption to be financed by an income tax. If the budget has to balance period by period, the tax rate becomes countercyclical. In good states of nature with high income, the tax rate is low, and vice versa in a bad states of nature with low income. This will tend to reinforce the fluctuations in disposable income. If instead a non-balanced budget is allowed it is optimal to have a procyclical tax rate and budget. In good states of nature the tax rate is increased and the budget in surplus, and vice versa in bad states of nature. This implies that disposable income and thus consumption is stabilized or smoothened. If this form of diversification cannot be established in private markets, ${ }^{23}$ and agents are risk averse there are clear welfare gains from such a policy. Notice that a procyclical tax rate $(\eta>0)$ achieves more risk diversification of disposable income than a proportional tax rate $(\eta=0)$. This result on the tax structure holds also with endogenous production where the business cycle is generated by e.g. productivity shocks, and the tax instrument is an income tax, which distorts

\footnotetext{
${ }^{20}$ This holds for $\tau\left(Y_{i}\right)\left[1+\eta\left(Y_{i}\right)\right]>0$, which has as a sufficient condition $\tau\left(Y_{i}\right)>0$ and $\eta\left(Y_{i}\right) \geqslant 0$.

${ }^{21}$ Note that the insurance effect is present to idiosyncratic shocks even though Ricardian equivalence holds in the aggregate, since this form of risk diversification can be achieved via a balanced budget, and therefore the basic effect does not rely on budget imbalances affecting behaviour.

${ }^{22}$ For instance risk diversification across different generations.

${ }^{23}$ Private markets may e.g. have difficulties in diversifying aggregate persistent shocks.
} 
the labour supply decision (see Andersen and Dogonowski (2002)). Hence, the contingency built into the taxation scheme works both to diversify idiosyncratic and aggregate risk. This also brings forth the close relationship between welfare arrangements and stabilization policy.

In practice it is easier to implement stabilizers working through taxation and transfer payments. On the expenditures side it is more difficult except for expenditures directly related to unemployment. Beyond that there is some scope for introducing contingencies on the consumption side via e.g. nominal budgeting rules. However, such rules introduce variability in public consumption to which agents may be equally risk averse as to variability in public consumption, and it is therefore not obvious that it is desirable to strengthen stabilizers on the expenditure side, cf.. above. An exception is public investment (in infrastructures etc.) since the marginal social costs of such projects are smaller in a recession than in an upswing, and this gives an argument for making such activities countercyclical. Given the time lags involved in most public investment projects, there is a question of how far it is possible to go in establishing the proper cyclical dependency in public sector investments.

\section{Shocks - type and persistence}

The automatic stabilizers arising from contingencies built into tax, social and labour market policies etc. have the advantage that they have zero information and implementation lags, and in general also a short impact lag. This is unique also compared to monetary policy. However, by the nature of being automatic it follows that they do not distinguish between the type of shock affecting say income. Two dimensions of the shock are important, namely the nature of the shock (demand or supply) and its persistence (temporary or permanent).

Is it a problem that the response is the same irrespective of the nature of the shock? That is, independently of whether the shock arises on the demand or the supply side, the automatic stabilizers tend to react to the implied responses in e.g. income. The answer to this question is complicated. First, the automatic stabilizer arising via the tax system works in the right direction to stabilize disposable income and therefore private consumption irrespective of whether shocks arise on the demand or the supply side (see Andersen and Dogonowski (2002)). In general it also works to stabilize activity. However, the stabilization of activity required is in general different for demand and supply shocks, and this creates a potential problem. This can be exemplified by the result from Andersen and Holden (2002), in which the role of fiscal stabilization policy is considered for a two sector (tradeables and non-tradeables) open economy, in which fiscal policy runs via public demand for non-tradeables, cf.. section 2.2. In this particular setting it is shown that stabilization of private consumption is tantamount to stabilizing the terms of trade. However, the effects on the terms of trade of supply (productivity) and demand shocks are in general opposite in direction, and therefore the optimal fiscal policy response is shock dependent. In this framework stabilization from the tax side would work in the right direction for both types of shocks, but the required adjustment would be shock dependent. For automatic stabilizers primarily running via taxation, however, it is difficult to imagine a system where the automatic tax response depends on the type of 
shock to income. ${ }^{24}$ Some differentiation to the response to different types of shocks may be the result of the particular tax system adopted, but this issue has not been carefully analysed in the literature. In any case, given that the stabilizers are rule based they would in practice have to operate across different types of shocks, therefore they may be inappropriate for a particular type of shock and still have desirable properties on average, see e.g. Spange (2004).

Another important point is that automatic stabilizers cannot distinguish between temporary and permanent changes. The effects of aggregate shocks are reflected in the budget balance and thereby accumulate over time if shocks are persistent. The consequences of the past are therefore always reflected in the budget (debt) position for the public sector. The reason why this is important can most easily be seen by returning to the role taxation has in terms of automatic stabilization or insurance to variations in income. The public sector provides an insurance function by raising more tax revenue in periods with high income, and vice versa, cf.. above. This shows up as a procyclical budget. However, the insurance which should be provided depends on the nature of the shock, cf.. appendix $B$. Clearly, the case of a transitory shock leaves room for diversification of the shock, while oppositely it is not possible to diversify a permanent shock. If a permanent shock hits the economy, the budget will display a systematic tendency towards budget imbalance, which is not sustainable (in the case of adverse shocks due to solvency, and for favourable shocks due to political reasons). However, automatic stabilizers entail an adjustment that is the same irrespective of the nature of the shock to income - transitory or permanent and it is not realistic to perceive an implementable taxation system which does not suffer from this problem. This has two implications. First, while the budget provides some insurance, we are in a second best situation since the insurance is not optimal across various temporal properties of the shock. Second, in practice, persistent shocks would call for discretionary changes in fiscal policy to ensure sustainability. This brings forth the important information problem of figuring out whether shocks are temporary or permanent, since discretionary changes in fiscal policy are necessary in the latter but not former case. The development from the mid 1970's and onwards for many industrialized countries is a case in point, since the crisis was perceived to be temporary, and the automatic stabilizers were doing their job. The recession turned out to be more persistent than perceived, and substantial budget balance problems were created, which eventually called for discretionary changes in fiscal policy to consolidate budgets. It follows that there is no such thing as purely automatic reactions in fiscal policy.

\section{Automatic stabilizers - too weak or too strong?}

\footnotetext{
${ }^{24}$ Finally, note that it is also possible to design fiscal rules that pay attention to the implications for prices, since that is a question of nominal vs. real budgeting rules in the public sector (see Andersen and Holden (2002)). The question of real vs. nominal budgeting procedures is interesting since it brings up the trade-off between price and output stabilization extensively debated in relation to monetary policy rules. Nominal budgeting rules will obviously contribute to achieving price stability, but they may cause more instable activity and therefore consumption. The reason is that e.g. a negative supply shock will increase prices, which then tend to reduce real public demand and therefore enlarge the real response to the shock
} 
Automatic stabilizers are widely appreciated, and a current consensus view seems to be that fiscal policy should primarily be left to the automatic stabilizers $^{25}$. Automatic stabilizers are quantitatively important in all OECD countries, and the response is primarily generated from variations in taxation and transfer payments, whereas public consumption plays a more modest role (see e.g. van der Noord (2000), Auerbach and Feenberg (2000), and Braconier and Holden (2001)). Moreover, there is a clear positive relation between the size of automatic stabilizers and the size of the public sector.

A number of studies have assessed the stabilizing effects of the automatic stabilizers and have found that they have contributed to sizeable reductions in output variability (see e.g. van der Noord (2000), Cohen and Follette (2000), Brunilla et. al. (2002)).

Despite the strong emphasis on the automatic stabilizers, there has been very scant discussion of whether the automatic stabilizers have the appropriate strength. Given the broad consensus to let automatic stabilizers take care of short run fiscal stabilization policy, this is surprising. With substantial variations in the size of the automatic stabilizers across countries, it is obvious to ask whether they are too strong or too weak. Since they work, they could be either too weak (in some countries) or too strong (in other countries). An important issue here is whether the automatic stabilizers have the size they have by construction or by hazard. On one hand, the empirical evidence clearly indicates that other policy decisions determining the size of government also have implications for the size of automatic stabilizers. It is difficult to perceive a large public sector without automatic stabilizers becoming strong (not least from the taxation side). On the other hand, when automatic stabilizers are interpreted as providers of social or implicit insurance, it follows that automatic stabilizers can be seen as the response to aggregate shocks arising from arrangements also serving a purpose in addressing idiosyncratic shocks. In this perspective one would expect countries with extended welfare states also to have strong automatic stabilizers because both reflect the same underlying demand for insurance.

The role of automatic stabilizers as providers of insurance is important in relation to debates about the need for reforms of e.g. taxation system, social security arrangements etc. Much of the policy debate and the academic literature has focused on the incentive effects of these arrangement while neglecting the insurance aspects. Accordingly, such analysis may overstate the costs of various policies by neglecting the insurance aspects. The trend in tax reforms has thus been to broaden tax bases and lowering marginal tax rates. While this may have beneficial incentive effects, these policy changes may also reduce automatic stabilizers and thus have a cost in increased volatility at the individual and aggregate level. Knieser and Ziliak (2002) consider the effects of tax reform in the US during the 1980s from this perspective, and find that the welfare costs from less insurance can be large, especially for relatively risk averse households facing large income risk. Buti and van der Noord (2003) consider the

\footnotetext{
${ }^{25}$ This is clear in the socalled Maastricht assignment for the European Monetary Union leaving centralized monetary policy to stabilize inflation, and decentralized fiscal authorities to stabilize national output by primarily relying on the automatic stabilizers.
} 
same aspects from the perspective of different types of shocks and the openness of economies, and argue based on an empirical analysis for European countries, that the automatic stabilizers may be too strong for some (very open) countries.

It is interesting to note one recent attempt to strengthen automatic stabilizers, namely the buffer funds in Finland (see Pekkarinen (2001)) to ensure more flexibility within the EMU. The scheme works via payroll taxes, and previously a balanced budget rule made them move counter-cyclically. The funds make the payroll taxes proportional (within limits) and thereby strengthen automatic stabilizers $^{26}$ (working via the supply side).

Finally, Buti et. al. (2003) raise the point that automatic stabilizers both have a demand and a supply channel. The demand channel is the well-known effect running via disposable income, cf.. above, while the supply channel arises because automatic stabilizers may also affect supply incentives and thus the slope of the (short-run) aggregate supply curve. Buti et. al. (2003) use a standard AS-AD macromodel and argue that stronger automatic stabilizers may lead to a more inelastic aggregate supply curve and therefore the net effect of automatic stabilizers depends both on the type of shocks and the structure of supply and demand (related to the level of taxation). It is argued that the automatic stabilizers may stabilize demand shocks, but de-stabilize supply shocks. It is an interesting issue for further research to investigate the implications of automatic stabilizers on the supply side. In an explicit microfounded model, Andersen and Spange (2004) have both the supply and demand effects of automatic stabilizers, and find that standard conclusions hold, even though business cycles are driven by supply (technology) shocks. It is, however, well-known that the effects of taxation depend critically on the specification of imperfections in labour and product markets, and therefore there is need for more research in this area.

\section{Implementing stabilization policy - discretion vs. rules}

There is a fundamental question of rules vs. discretion in stabilization policy. The debate in monetary policy is well-known, and reflected in the focus on independent central banks and rule based monetary policies. Many of the same issues arise for fiscal policy.

Consider discretionary fiscal policy. A key lesson from the theoretical considerations is that the case for an active stabilization policy rests on two conditions, i) the policy intervention is dependent on market imperfections and shocks, ii) the intervention should be temporary in the sense that the timing should reflect the shocks and the adjustment mechanisms working in the economy. This raises problems in relation to both information and implementation and in relation to credibility and time-consistency.

${ }^{26}$ In principle the scheme also allows for the use of the fund in discretionary moves. 
It is obvious that an appropriate discretionary fiscal policy puts strong informational demands in relation to knowledge on both the economic structure (in particular adjustment processes) and the shocks impinging on the economy. The latter includes both its nature (supply vs. demand) and its persistence (temporary or vs. permanent). Some lags are inevitable in the process of accumulating information, to which can be added lags in implementing the policy changes and finally the effect lags. All of these steps entail uncertainty, and the lags raise a fundamental problem in targeting discretionary changes. When the policy has effect, would the need still be present? These problems point in the direction of being very cautious in the use of discretionary policy changes and restricting the use to the case of "large" shocks or situations where the economy is caught in an expectation trap keeping output at a permanently low level. ${ }^{27}$ Hence, in "normal" situations one should leave fiscal stabilization to the automatic stabilizers. Although they are not perfect, they operate automatically and are informationally less demanding.

There are also various political economy or strategic aspects associated with fiscal policy. Fiscal policy may have a time-consistent problem, which is qualitatively very similar to that of monetary policy. The temporary nature of the intervention is important. Hence, there may be an incentive for policy markers to undertake such changes and announce them as temporary. However, ex post there may not be an incentive to redress the policy change. To the extent that this is perceived, the effectiveness of the intervention is reduced, cf.. section 4 . This is related to the issue of potential political bias or myopia, which may create an incentive to run systematic budget deficits since tax increases to finance expanded outlays are postponed (see e.g. Alesina and Perotti (1995)).

To overcome the political bias problems in fiscal policy it has been suggested $^{28}$ to establish a "fiscal board" responsible for fiscal stabilization policy (see e.g. Seidman (2001) for an account of the origin of this idea and Calmfors (2003) for an overview of the recent debate). This idea is inspired by the debate on and the subsequent establishment of independent central banks assigned a well defined objective. In a similar vein the idea of a "fiscal board" is to delegate fiscal decision making to an independent institution to eliminate short run opportunistic behaviour in affecting fiscal policies. Such a board would thus ensure that changes in fiscal policy to stabilize the economy are both well adapted to the business cycle situation and are temporary in nature. Thereby two problematic aspects related to discretionary fiscal stabilization policies could be reduced.

Various proposals have been made in the literature for the structure and mandate for such a fiscal board. The main idea is that politicians should decide on the overall structure of fiscal policy depending on the political preferences for public sector activities given the constraint of fiscal sustainability. The fiscal board is entrusted with the responsibility for short run changes in fiscal policy aiming at stabilizing the economy. A more soft version of the idea is that

\footnotetext{
${ }^{27}$ See e.g. van Haan (2004). Note that it is in itself informationally demanding to establish whether there are multiple equilibria.

${ }^{28}$ In Sweden there has been an explicit proposal for such a board, see Swedish Commission on Stabilization Policy in EMU.
} 
the board does not have any formal decision power, but plays the role of an advisory board making recommendations on the room and scope for changes in fiscal policy, and thereby raising the political cost of opportunistic policies.

One problem with this proposal is that it implicitly relies on the perception that it is possible to separate the tasks of allocation, distribution and stabilization for governments. Although this problem can also be said to be present for monetary policy, it is the case that fiscal policy to a larger extent relates to distributional issues. As argued above, it is impossible to separate the distributional and insurance aspects, and therefore the democratic deficit in delegating fiscal policy will be larger than for monetary policy. It is therefore hardly realistic to foresee politicians accepting the idea of an independent fiscal board as easily as an independent central bank. This could also be expressed in the way that it would be more difficult to formulate a precise mandate for a fiscal board than for a central bank.

Another point is that an attempt to separate stabilization and allocation may restrict the feasible policy options. Often reforms aiming at allocational objectives will also have potential short "stabilization" effects. If there are e.g. good reasons to implement a tax reform, it may be appropriate to do this when the economy is also in need of a fiscal stimulus, since the two objectives can be met by phasing in the tax reform such that it initially is "underfinanced". This may also make it easier to attain support for the reform. With short run stabilization delegated to an independent fiscal board, it would be very difficult to implement such a "package", or to put it differently, it raises new coordination issues.

\section{Concluding remarks}

A key distinction, which is often confused in the literature, is between the longrun effects of fiscal policy and stabilization policy. By the former is understood the long run effects of permanent changes in public consumption and taxation, while by stabilization policy is understood temporary variations in public consumption and taxes. In most models, the long run effects of fiscal policy are driven by supply effects, i.e. aggregate demand plays no role for the level of activity, and therefore the effects of fiscal policy become a question of how various supply incentives are affected. It is misleading to infer anything about the scope for an active fiscal stabilization policy. from the long run effects of changes in fiscal policy. If aggregate demand plays a role for determination of activity in the short run, it follows that temporary variations in public consumption or taxation can have important effects and can be used to stabilize the economy, even though the long run multipliers may be negative.

The critical question for an active fiscal stabilization policy is the ability to adjust the intervention appropriately given the nature of shocks and the structure of the economy. It is much easier to establish a principle case for an active stabilization policy than to implement it in practice. There are thus good reasons to be very cautious in the use of fiscal stabilization policy in the sense of 
only resorting to such measures in "exceptional" situations. In "normal" cases stabilization should be left to the automatic stabilizers.

However, automatic stabilizer are what they are more by chance than by design, that is, they are the net result of policy decisions in various areas, which rarely are made with a consideration of their effect for the overall strength of the automatic stabilizers. More research on these issues is needed for several reasons. First, to consider whether it is possible to amend the automatic stabilizers through other means, e.g. buffer funds. Second to take into account the trade off between insurance and incentive when considering policy reforms in other areas. Finally, to consider the scope for refining the automatic stabilizers so that they work more appropriately for various types of shocks. Given the reliance on automatic stabilizers, the marginal value of further insights on these issues is potentially large.

\section{Appendix A}

This appendix develops an illustrative intertemporal model to show the potential stabilizing role of fiscal policy.

Firms: A representative price taking firm is producing subject to the technology

$$
Y=\frac{1}{\delta} L_{t}^{\delta} Z_{t} \quad, \quad 0<\delta<1
$$

where $Y$ denotes output, $L$ labour input, and $Z$ a productivity shocks, cf. below. In logs labour demand and output supply can be stated as $(x \equiv \ln X)$

$$
\begin{aligned}
& l^{d}=\epsilon\left(p_{t}-w_{t}+z_{t}\right) ; \epsilon=\frac{1}{1-\delta} \\
& y^{s}=\gamma\left(p_{t}-w_{t}\right)+\epsilon z_{t} ; \gamma=\frac{\delta}{1-\delta}
\end{aligned}
$$

It is assumed that $z_{t}$ is $i i d N\left(0, \sigma^{2}\right)$.

Households: Let the utility function for the representative household be given by

$$
E_{t} \sum_{i=0}^{\infty} \beta^{i}\left[\frac{1}{1-\gamma} C_{t+i}^{1-\gamma}+\frac{1}{1-\eta}\left(1-L_{t+i}\right)^{1-\eta}+\frac{1}{1-\xi}\left(\frac{M_{t+i}}{P_{t+i}}\right)^{1-\xi}\right]
$$

where $C$ denotes consumption, $L$ work and $\left(\frac{M}{P}\right)$ the liquidity services provided by holding money. The intertemporal budget constraint reads

$\sum_{i=0}^{\infty}\left(\prod_{j=1}^{i}\left(\frac{1}{1+i_{t+j}}\right)\right) P_{t+i} C_{t+i}=\sum_{i=0}^{\infty}\left(\prod_{j=1}^{i}\left(\frac{1}{1+i_{t+j}}\right)\right)(1-\tau)\left[W_{t+i} L_{t+i}+\Pi_{t+i}\right]$

where $i_{t+j}$ is the one period nominal rate of interest in period $t+j, \tau$ the income tax rate, and $\Pi$ the profits distributed to households due to their ownership of firms. 
Consumption: The Euler equation reads

$$
C_{t}^{-\gamma}=\beta E\left[C_{t+1}^{-\gamma} \frac{\left(1+i_{t}\right) P_{t}}{P_{t+1}}\right]
$$

which written in logs reads (disregarding constants)

$$
c_{t}=E c_{t+1}-\sigma\left(i_{t}-\left(E p_{t+1}-p_{t}\right)\right)
$$

where $\sigma=\frac{1}{\gamma}$ and $\ln (1+i) \cong i$.

\section{Wage setting}

Assume that wages are pre-set by a utilitarian union under a right to manage structure, i.e. the union knows that labour demand is determined by (2). The first order condition for wage formation is

$$
E_{t-1}\left[(1-\tau) \frac{W_{t}}{P_{t}} C_{t}^{-\gamma}\right]=E_{t-1}\left[\left(1-L_{t}\right)^{-\eta} \epsilon\right]
$$

where $\epsilon$ is the elasticity of labour demand. Using that all stochastic variables have expected values zero, it follows that the wage setting rule can be written

$$
w_{t}=\omega+E_{t-1} p_{t}
$$

Actual employment is determined by labour demand as long as the marginal rate of substitution between labour and consumption exceeds the real wage rate, i.e.

$$
(1-\tau) \frac{W_{t}}{P_{t}} C_{t}^{-\gamma} \geq\left(1-L_{t}\right)^{-\eta} \epsilon
$$

For latter reference denote the maximum employment level satisfying this constraint $\bar{l}$. Using (5) and (3) aggregate supply can be written (neglecting constants)

$$
y_{t}^{s}=\gamma\left(p_{t}-E_{t-1} p_{t}\right)+\epsilon z_{t}
$$

\section{Interest rate setting}

The central bank is determining the nominal interest rate (money supply is therefore accommodation money demand) and for simplicity the policy reaction function is postulated to be

$$
i_{t}=r+\chi\left(p_{t}-p_{t-1}\right)
$$

i.e. the higher the observed inflation $\left(p_{t}-p_{t-1}\right)$ the higher the nominal interest rate set by the central bank. The parameter $\chi$ measure how aggressive the central bank reacts to observed inflation. Inserting (7) in (4) yields

$$
c_{t}=E c_{t+1}-\sigma\left(\chi\left(p_{t}-p_{t-1}\right)-\left(E p_{t+1}-p_{t}\right)\right)
$$

\section{Public sector}


Public consumption is exogenous, and the intertemporal budget constraint reads

$\sum_{i=0}^{\infty}\left(\prod_{j=1}^{i}\left(\frac{1}{1+i_{t+j}}\right)\right) P_{t+i} G_{t+i}=\tau \sum_{i=0}^{\infty}\left(\prod_{j=1}^{i}\left(\frac{1}{1+i_{t+j}}\right)\right)\left[W_{t+i} L_{t+i}+\Pi_{t+i}\right]$

The level of public consumption in any period (deviation from steady state) is given as

$$
g_{t}=\mu_{t}
$$

where $\mu$ has the interpretation as either an exogenous change in public consumption, or a discretionary change in fiscal policy conditional on some underlying changes in the state of the economy. It is assumed that $E_{t-1} \mu_{t}$.

\section{Product market equilibrium}

The equilibrium condition for the product market $Y_{t}=C_{t}+G_{t}$ can be written in $\log \mathrm{s}^{29}$

$$
y_{t}=(1-\lambda) c_{t}+\lambda g_{t}
$$

This gives the aggregate demand relation which combined with the aggregate supply relation (6)

It is easiest to solve the model by the undetermined coefficients methods, and to this end conjecture that consumption in equilibrium is given as

$$
c_{t}=\varphi_{1} \mu_{t}+\varphi_{2} z_{t}
$$

note that this implies $E c_{t+1}=0$, and equilibrium prices are given as

$$
p_{t}=\theta_{1} p_{t-1}+\theta_{2} \varepsilon_{t}+\theta_{3} z_{t}
$$

To verify these conjectures using (10) in (8) and (6) implies that the equilibrium price level can be written

$$
p_{t}=\left[\gamma+(1-\lambda) \sigma\left(\chi-\left(\theta_{1}-1\right)\right)\right]^{-1}\left[\left(\gamma \theta_{1}+(1-\lambda) \sigma \chi\right) p_{t-1}+\lambda \varepsilon_{t}-\epsilon z_{t}\right]
$$

which is consistent with (10) provided

$$
\begin{aligned}
\theta_{1} & =\frac{\gamma \theta_{1}+(1-\lambda) \sigma \chi}{\gamma+(1-\lambda) \sigma\left(\chi-\left(\theta_{1}-1\right)\right)}=\chi \\
\theta_{2} & =\frac{\lambda}{\gamma+(1-\lambda) \sigma} \\
\theta_{3} & =-\frac{\epsilon}{\gamma+(1-\lambda) \sigma}
\end{aligned}
$$

Using the solution for the price level in the aggregate supply relation (6) equilibrium activity can be determined as

\footnotetext{
${ }^{29}$ Using the approximation $\ln \left(X_{t}+Y_{t}\right) \simeq \frac{X}{X+Y} \ln X_{t}+\frac{Y}{X+Y} \ln Y_{t}$, where $X$ and $Y$ denote the steady state values of $X_{t}$ and $Y_{t}$, respectively.
} 


$$
y_{t}=\gamma \theta_{2} \mu_{t}+\left(\gamma \theta_{3}+\epsilon\right) z_{t}
$$

Note that

$$
\begin{aligned}
& 0<\gamma \theta_{2}=\frac{\gamma \lambda}{\gamma+(1-\lambda) \sigma \chi} \leq \lambda \\
& 0<\gamma \theta_{3}+\epsilon=\epsilon\left(-\frac{\gamma}{\gamma+(1-\lambda) \sigma \chi}+1\right)=\epsilon\left(\frac{(1-\lambda) \sigma \chi}{\gamma+(1-\lambda) \sigma \chi}\right) \leq \epsilon
\end{aligned}
$$

i.e. both public consumption and productivity shocks boost activity, but the effect on equilibrium output is less than the impact effect, i.e. there is some crowding out. Note that this holds only for $y_{t}<\overline{y_{t}}=\delta \overline{l_{t}}+z_{t}$

Using (8) we have that private consumption is given as (for $y_{t}<\overline{y_{t}}$ ).

$$
\begin{aligned}
c_{t} & =\frac{1}{1-\lambda}\left[y_{t}-\lambda g_{t}\right] \\
& =\epsilon\left(\frac{\sigma \chi}{\gamma+(1-\lambda) \sigma \chi}\right) z_{t}-\frac{1}{\lambda}\left[\frac{(1-\lambda) \sigma \chi}{\gamma+(1-\lambda) \sigma \chi}\right] \mu_{t}
\end{aligned}
$$

which is consistent with the conjecture (9) when

$$
\begin{aligned}
& \varphi_{1}=-\frac{1}{\lambda}\left[\frac{(1-\lambda) \sigma \chi}{\gamma+(1-\lambda) \sigma \chi}\right] \\
& \varphi_{2}=\epsilon\left(\frac{\sigma \chi}{\gamma+(1-\lambda) \sigma \chi}\right)
\end{aligned}
$$

\section{Appendix B}

This appendix clarifies the different scope in diversifying transitory and permanent shocks via automatic stabilizers.

For the sake of argument consider the limiting case where there is no private capital market for human capital, implying that all agents are liquidity constrained, that is, consumption $(C)$ is equal to current (labour) income $(Y)$ assumed to be time dependent, i.e.

$$
C_{t}=Y_{t}
$$

Assume that agents are infinitely lived with a utility function defined over consumption

$$
\sum_{j=0}^{\infty} \beta^{j} U\left(C_{t+j}\right)
$$

where $\beta$ is the subjective discount factor. It is a straightforward implication of risk aversion $\left(U^{\prime}>0, U^{\prime \prime}<0\right)$ that there are welfare gains to be reaped by smoothing consumption. Since this is not possible for private agents due to capital market incompleteness, the question is what type of smoothing should be offered by the public sector. 
Consider first the optimal consumption smoothing a central planner will choose if resources can be transferred over time via e.g. an international capital market at a real rate of return $\mathrm{r}$ (assumed constant). In this case the intertemporal budget constraint reads

$$
\sum_{j=0}^{\infty}\left(\frac{1}{1+r}\right)^{j} C_{t+j}=\sum_{j=0}^{\infty}\left(\frac{1}{1+r}\right)_{t+j}^{j} Y_{t+j}
$$

where $r$ is the market interest rate (assumed constant for simplicity). Consumption smoothing implies that

$$
C_{t+j}=C=\frac{r}{1+r} \sum_{j=0}^{\infty}\left(\frac{1}{1+r}\right)^{j} Y_{t+j}
$$

It is an implication that consumption should adapt to a transitory change in demand by

$$
\frac{\partial C}{\partial Y_{t+j}}=\frac{r}{1+r}
$$

and to a permanent change in income by

$$
\left.\frac{\partial C}{\partial Y}\right|_{Y_{t+j=y}}=1
$$

The basic point is that the optimal smoothing or risk diversification calls for different adjustment to transitory and permanent changes in income. This insight clearly generalizes beyond the specific example considered here.

Turn next to diversification offered by the public sector via automatic stabilizers. If we focus on the insurance effect disregarding the need to finance public expenditures (could easily be integrated), then the budget constraint for intertemporal reallocation reads

$$
0=\sum_{j=0}^{\infty}\left(\frac{1}{1+r}\right)^{j} T_{t+j}
$$

Assume that the transfer is implemented as a tax on income, i.e.

$$
T_{t+j}=\tau\left(y_{t+j}\right) y_{t+j}
$$

where $\tau\left(y_{t+j}\right)$ gives the tax rate as a function of income. The consumption for a liquidity constrained household reads

$$
c_{t+j}=\left(1-\tau\left(y_{t+j}\right)\right) y_{t+j}
$$

and the adjustment of consumption to a change in income will be given as

$$
\frac{\partial c_{t+j}}{\partial y_{t+j}}=1-\tau\left(y_{t+j}\right)-\tau^{\prime}\left(y_{t+j}\right) y_{t+j}
$$


For the consumption of liquidity constrained households to become equivalent to the optimal adjustment to temporary variations in income, we require

$$
1-\tau\left(y_{t+j}\right)-\tau^{\prime}\left(y_{t+j}\right) y_{t+j}=\frac{r}{1+r}
$$

or

$$
\begin{aligned}
\tau\left(y_{t+j}\right)\left[1+\frac{\partial \tau\left(y_{t+j}\right)}{\partial y_{t+j}} \frac{y_{t+j}}{\tau\left(y_{t+j}\right)}\right] & =\frac{1}{1+r} \\
\frac{\partial \tau\left(y_{t+j}\right)}{\partial y_{t+j}} \frac{y_{t+j}}{\tau\left(y_{t+j}\right)} & =\frac{1-\tau\left(y_{t+j}\right)(1+r)}{\tau\left(y_{t+j}\right)(1+r}>0
\end{aligned}
$$

that is, the tax rate has to move procyclically. However, for a permanent income change, we require

$$
\begin{aligned}
1-\tau\left(y_{t+j}\right)-\tau^{\prime}\left(y_{t+j}\right) y_{t+j} & =1 \\
\frac{\partial \tau\left(y_{t+j}\right)}{\partial y_{t+j}} \frac{y_{t+j}}{\tau\left(y_{t+j}\right)} & =-1
\end{aligned}
$$

the tax rate has to move countercyclical to ensure that the transfer is unaffected. Clearly, a more complicated and realistic case involves shocks that are persistent but not permanent. This example has the following implications: (i) it is impossible by simple contingencies in taxation to ensure optimal risk diversification to both transitory and permanent shocks (conditions (11) and (12) cannot be simultaneous fulfilled), (ii) a given choice of a rule would require discretionary changes once information on the type of shock unravels since permanent shocks would be reflected in debt dynamics.

\section{References}

[1] Alesina, A., S. Ardagna, R. Perotti and F. Schiantarelli, 2002, Fiscal Policy, Profits and Investments, American Economic Review, 92, 571-589.

[2] Alesina, A. and R. Perotti, 1995, The Political Economy of Budget Deficits, IMF Staff Papers, 42, 1-3.

[3] Andersen, T.M., 2004, Fiscal Stabilization Policy in a Small Open Economy, Working Paper.

[4] Andersen, T.M. and R. Dogonowski, 2002, Social Insurance and the Public Budget, Economica, 69, 415-432.

[5] Andersen, T.M. and S. Holden, 2002, Fiscal Stabilization Policy in an Open Economy, Journal of Macroeconomics, 24, 293-312.

[6] Andersen, T.M. and M. Spange, 2004, International Interdependencies in Fiscal Stabilization Policy, European Economic Review (to appear). 
[7] Auerbach, A.J., 2003, Fiscal Policy, Past and Present, Brookings Papers on Economic Activity, 75-138.

[8] Auerbach, A.J. and D. Feenberg, 2000, The Significance of Federal Taxes as Automatic Stabilizers, Journal of Economic Perspectives, 14, 37-56.

[9] Barr, N., 2004, The Economics of the Welfare State, 4th ed., Oxford University Press.

[10] Baxter, M. and R. King, 1993, Fiscal Policy in General Equilibrium, American Economic Review, 83, 315-334.

[11] Benassy, J.-P., 2002, Macroeconomics of Imperfect Competition and Nonclearing Markets - A Dynamic General Equilibrium Approach, MIT Press.

[12] Bertola, G. and A. Drazen, 1993, Trigger Points and Budget Cuts: Explaining the Effects of Fiscal Austerity, American Economic Review, 83, $11-26$.

[13] Blanchard, O. and R. Perotti, 2002, An Empirical Characterization of the Dynamic Effects of Changes in Government Spending on Output, Quarterly Journal of Economics, 111,1329-68.

[14] Braconier, H. and S. Holden, 2001, Measuring Changes in Fiscal Policy, Working Paper.

[15] Brunilla, A., M. Buti and J. in’t Veld, 2002, Fiscal Policy in Europe: How Effective Are Automatic Stabilisers?, European Economy, Economic Papers 177, European Commission.

[16] Buti, M. and P. van der Noord, 2003, What Is the Impact of Tax and Welfare Reforms on Fiscal Stabilizers: A Simple Model and an Application to EMU, European Economy, Economic Papers 187, European Commission.

[17] Buti, M., C. Martinez-Mongay, K. Sekkat and P. van der Noord, 2003, Automatic Fiscal Stabilizers in EMU: A Conflict between Efficiency and Stabilization, CESifo Economic Studies, 49, 123-140.

[18] Calmfors, L., 2003, Fiscal Policy to Stabilize the Domestic Economy in the EMU, CESifo Economic Studies, 49, 319-354.

[19] Campbell, J.Y. and N.G. Mankiw, 1991, The Response of Consumption to Income: A Cross-Country Investigation, European Economic Review, 35, 732-767.

[20] Carroll, C.D., 2001, A Theory of the Consumption Function, With and Without Liquidity Constraints, Journal of Economic Perspectives, 15, 2345 . 
[21] Clarida, R., J. Gali and M. Gertler, 1999, The Science of Monetary Policy - A New Keynesian Perspective, Journal of Economic Literature, XXXVII,1661-1707.

[22] Cogley, T. and J.M. Mason, 1995, Output Dynamics in Real-Business-Cycle Models, American Economic Review, 85, 492-511.

[23] Cohen, D. and G. Follette, 2000, The Automatic Stabilizers: Quietly Doing Their Thing, FRBNY Economic Policy Review, 35-68.

[24] Dixon, H., 1987, A Simple Model of Imperfect Competition with Walrasian Features, Oxford Economic papers, 39,134-60.

[25] Dixon, H. and P. Lawler, 1996, Imperfect Competition and the Fiscal Multiplier, Scandinavian Journal of Economics, 98, 219-232.

[26] Dixon, H.D. and N. Rankin, 1994, Imperfect Competition and Macroeconomics: A Survey, Oxford Economic Papers, 171-195.

[27] Domar, E. and R.A. Musgrave, 1944, Proportional Taxation and Risk Sharing, Quarterly Journal of Economics, 58, 388-422.

[28] Dynarski, S., J. Gruber, R.A. Moffitt and G. Burtless, 1997, Can Families Smooth Variable Earnings?, Brookings Papers on Economic Acitivity, 229303.

[29] Fatás and Mihov, 2003, The Case for Restricting Fiscal Policy Discretion, Quarterly Journal of Economics, 118,1419-1477.

[30] Gali, J., M. Gertler, and D. Lopez-Salido, 2003,Markup, Gaps, and the Welfare Costs of Business Fluctuations, working paper.

[31] Gali, J. and R. Perotti, 2003, Fiscal Policy and Monetary Integration in Europe, Economic Policy., 535-572.

[32] Giudice, G., A. Turrini and J. in't Vald, 2003, Can Fiscal Consolidations be Expansionary in the EU? Ex-post Evidence and Ex-ante Analysis, European Economy, Economic Papers 195, European Commission.

[33] Gordon, R. and H.R. Varian, 1988, Intergenerational Risk Sharing, Journal of Public Economics, 37, 185-202.

[34] Gruber, J., 1997, The Consumption Smoothing Benefits of Unemployment Insurance, American Economic Review, 87, 192-205.

[35] Hairualt, J.-O. and F. Portier, 1993, Money, New-Keynesian Macroeconomics and the Business Cycle, European Economic Review, 37, 1533-1568.

[36] Hemming, R., M. Kell and S. Mahfouz, 2002, The Effectiveness of Fiscal Policy in Stimulating Economic Activity - A Review of the Literature, IMF Working Paper WP/02/208. 
[37] Jappelli, T. and M. Pagano, 1989, Consumption and Capital Market Imperfections: An International Comparison, American Economic Review, 79, 1088-1105.

[38] Knieser, T.J. and J.P. Ziliak, 2002, Tax Reform and Automatic Stabilization, American Economic Review, 92, 590-621.

[39] Lane, P., 2001, The new open economies macroeconomics: A Survey, Journal of International Economics, 54, 235-266.

[40] Lane, P., 2003, The cyclical properties of fiscal policy: Evidence from the OECD, Journal of Public Economics, 87, 2661-2675.

[41] Lucas, R., 1987, Models of the Business Cycle, Basil Blackwell, Oxford.

[42] Mankiw, N.G., 1988, Imperfect Competition and the Keynesian Cross, Economics Letters, 26, 7-13.

[43] Marston, R.C., 1985, Stabilization Policies in Open Economies, in R.W.Jones and P.B. Kenen (eds.), Handbook of International Economics, North-Holland, Amsterdam.

[44] Obstfeld, M. \& K. Rogoff, 2002, Global Implications of Self-oriented National Monetary Rules, The Quarterly Journal of Economics, 117, 503-35..

[45] Pekkarinen, J., 2001, Fiscal Policy and EMU: Finnish Perspective, in Fiscal Policy and EMU, Report of the Swedish Committee on Stabilization Policy in EMU, States Offentliga Utredninar, Stockholm.

[46] Pissarides, C., 1998, The Impact of Employment Tax Cuts on Unemployment and Wages: The Role of Unemloyment Benefits and Tax Structure, European Economic Review, 42, 155-184.

[47] Prescott, E.C., 1987, Theory ahead of Business Cycle Measurement, Carnegie-Rochester Conference Series on Public Policy, 25, 11-44.

[48] Ricciuti, R., 2003, Assessing Ricardian Equivalence, Journal of Economic Surveys, 17, 55-78.

[49] Romer, D.,1996 Advanced Macroeconomics, McGrawHill (New York).

[50] Sarantis, N. and C. Stewart, 2003, Liquidity Constraints, Precautionary Saving and Aggregate Consumption: An International Comparison, Economic Modelling, 20, 1151-1173.

[51] Seidman, L., 2001, Reviving Fiscal Policy, Challenge, 44, 17-42.

[52] Sinn, H-W., 1995, The Welfare Economics of the Welfare State, Scandinavian Journal of Economics, 97, 469-476.

[53] Spange, M., 2004, Optimal Automatic Stabilizers, Working Paper, University of Aarhus. 
[54] Stadler, P.1994, Real Business Cycle Models, Journal of Economic Literature, XXXII, 1750-1783.

[55] Storesletten, K., C.I. Telmer and A. Yaron, 2004, Cyclical Dynamics in Idiosyncratic Labour Market Risk, Journal of Political Economy, 112, 695716.

[56] Sutherland, A., 1997, Fiscal Crises and Aggregate Demand: Can High Public Debt Reverse the Effects of Fiscal Policy, Journal of Public Economics, 65.

[57] Svensson L.E.O,1999,Inflation Targeting as a Monetary Policy Rule, Journal of Monetary Economics, 43, 607-654.

[58] Svensson, L.E.O, and M. Woodford, 2005, Implementing Optimal Policy through Inflation-Forecast Targeting, in Bernanke, Ben S., and Michael Woodford, eds. (2005), The Inflation-Targeting Debate, University of Chicago Press, 19-83

[59] Taylor, J.B., 2000, Reassessing Discretionary Fiscal Policy, Journal of Economic Perspectives, 14, 21-36.

[60] van der Noord, P., 2000, Size of Automatic Stabilizers OECD Working Paper

[61] van Haan, W., 2004, Temporary Shocks and Unavoidable Transitions to a High-Unemployment Regime, Paper presented at the 5th ECB-CEPR Labour Market Conference.

[62] Varian, H.1980, Redistributive taxation as social insurance, Journal of Public Economics, 14, 49-68.

[63] Woodford, M. , 2003, Interest and Prices - Foundation of a Theory of Monetary Policy, Princeton University Press, Princeton. 


\title{
CESifo Working Paper Series
}

\author{
(for full list see www.cesifo.de)
}

1382 Christian Gollier, Optimal Illusions and Decisions under Risk, January 2005

1383 Daniel Mejía and Marc St-Pierre, Unequal Opportunities and Human Capital Formation, January 2005

1384 Luis H. R. Alvarez and Erkki Koskela, Optimal Harvesting under Resource Stock and Price Uncertainty, January 2005

1385 Ruslan Lukach, Peter M. Kort and Joseph Plasmans, Optimal R\&D Investment Strategies with Quantity Competition under the Threat of Superior Entry, January 2005

1386 Alfred Greiner, Uwe Koeller and Willi Semmler, Testing Sustainability of German Fiscal Policy. Evidence for the Period 1960 - 2003, January 2005

1387 Gebhard Kirchgässner and Tobias Schulz, Expected Closeness or Mobilisation: Why Do Voters Go to the Polls? Empirical Results for Switzerland, 1981 - 1999, January 2005

1388 Emanuele Bacchiocchi and Alessandro Missale, Managing Debt Stability, January 2005

1389 Assar Lindbeck and Dirk Niepelt, Improving the SGP: Taxes and Delegation rather than Fines, January 2005

1390 James J. Heckman and Dimitriy V. Masterov, Skill Policies for Scotland, January 2005

1391 Emma Galli \& Fabio Padovano, Sustainability and Determinants of Italian Public Deficits before and after Maastricht, January 2005

1392 Angel de la Fuente and Juan Francisco Jimeno, The Private and Fiscal Returns to Schooling and the Effect of Public Policies on Private Incentives to Invest in Education: A General Framework and Some Results for the EU, January 2005

1393 Juan C. Conesa and Carlos Garriga, Optimal Response to a Demographic Shock, January 2005

1394 Christian Gollier, Optimal Portfolio Management for Individual Pension Plans, February 2005

1395 Ruslan Lukach, Joseph Plasmans and Peter M. Kort, Innovation Strategies in a Competitive Dynamic Setting, February 2005

1396 Gebhard Kirchgässner, (Why) Are Economists Different?, February 2005

1397 Marko Köthenbürger, Panu Poutvaara and Paola Profeta, Why are More Redistributive Social Security Systems Smaller? A Median Voter Approach, February 2005 
1398 Gabrielle Demange, Free Choice of Unfunded Systems: A First Assessment, February 2005

1399 Carlos Fonseca Marinheiro, Sustainability of Portuguese Fiscal Policy in Historical Perspective, February 2005

1400 Roel M. W. J. Beetsma and Koen Vermeylen, The Effect of Monetary Unification on Public Debt and its Real Return, February 2005

1401 Frank Asche, Petter Osmundsen and Maria Sandsmark, Is It All Oil?, February 2005

1402 Giacomo Corneo, Media Capture in a Democracy: The Role of Wealth Concentration, February 2005

1403 A. Lans Bovenberg and Thijs Knaap, Ageing, Funded Pensions and the Dutch Economy, February 2005

1404 Thiess Büttner, The Incentive Effect of Fiscal Equalization Transfers on Tax Policy, February 2005

1405 Luisa Fuster, Ayşe İmrohoroğlu and Selahattin İmrohoroğlu, Personal Security Accounts and Mandatory Annuitization in a Dynastic Framework, February 2005

1406 Peter Claeys, Policy Mix and Debt Sustainability: Evidence from Fiscal Policy Rules, February 2005

1407 James M. Malcomson, Supplier Discretion over Provision: Theory and an Application to Medical Care, February 2005

1408 Thorvaldur Gylfason, Interview with Assar Lindbeck, February 2005

1409 Christian Gollier, Some Aspects of the Economics of Catastrophe Risk Insurance, February 2005

1410 Gebhard Kirchgässner, The Weak Rationality Principle in Economics, February 2005

1411 Carlos José Fonseca Marinheiro, Has the Stability and Growth Pact Stabilised? Evidence from a Panel of 12 European Countries and Some Implications for the Reform of the Pact, February 2005

1412 Petter Osmundsen, Frank Asche, Bård Misund and Klaus Mohn, Valuation of International Oil Companies -The RoACE Era, February 2005

1413 Gil S. Epstein and Shmuel Nitzan, Lobbying and Compromise, February 2005

1414 Marcel F. M. Canoy, Jan C. van Ours and Frederick van der Ploeg, The Economics of Books, February 2005 
1415 Eric A. Hanushek and Ludger Wößmann, Does Educational Tracking Affect Performance and Inequality? Differences-in-Differences Evidence across Countries, February 2005

1416 George Kapetanios and M. Hashem Pesaran, Alternative Approaches to Estimation and Inference in Large Multifactor Panels: Small Sample Results with an Application to Modelling of Asset Returns, February 2005

1417 Samuel Mühlemann, Jürg Schweri, Rainer Winkelmann and Stefan C. Wolter, A Structural Model of Demand for Apprentices. February 2005

1418 Giorgio Brunello and Lorenzo Rocco, Educational Standards in Private and Public Schools, February 2005

1419 Alex Bryson, Lorenzo Cappellari and Claudio Lucifora, Why so Unhappy? The Effects of Unionisation on Job Satisfaction, March 2005

1420 Annalisa Luporini, Relative Performance Evaluation in a Multi-Plant Firm, March 2005

1421 Giorgio Bellettini and Carlotta Berti Ceroni, When the Union Hurts the Workers: A Positive Analysis of Immigration Policy, March 2005

1422 Pieter Gautier, Michael Svarer and Coen Teulings, Marriage and the City, March 2005

1423 Ingrid Ott and Stephen J. Turnovsky, Excludable and Non-Excludable Public Inputs: Consequences for Economic Growth, March 2005

1424 Frederick van der Ploeg, Back to Keynes?, March 2005

1425 Stephane Dees, Filippo di Mauro, M. Hashem Pesaran and L. Vanessa Smith, Exploring the International Linkages of the Euro Area: a Global VAR Analysis, March 2005

1426 Hans Pitlik, Friedrich Schneider and Harald Strotmann, Legislative Malapportionment and the Politicization of Germany's Intergovernmental Transfer System, March 2005

1427 Konstantinos Angelopoulos and Apostolis Philippopoulos, The Role of Government in Anti-Social Redistributive Activities, March 2005

1428 Ansgar Belke and Daniel Gros, Asymmetries in the Trans-Atlantic Monetary Policy Relationship: Does the ECB follow the Fed?, March 2005

1429 Sören Blomquist and Luca Micheletto, Optimal Redistributive Taxation when Government's and Agents' Preferences Differ, March 2005

1430 Olof Åslund and Peter Fredriksson, Ethnic Enclaves and Welfare Cultures - QuasiExperimental Evidence, March 2005

1431 Paul De Grauwe, Roberto Dieci and Marianna Grimaldi, Fundamental and NonFundamental Equilibria in the Foreign Exchange Market. A Behavioural Finance Framework, March 2005 
1432 Peter Egger, Stefan Gruber, Mario Larch and Michael Pfaffermayr, Knowledge-Capital Meets New Economic Geography, March 2005

1433 George Economides and Apostolis Philippopoulos, Should Green Governments Give Priority to Environmental Policies over Growth-Enhancing Policies?, March 2005

1434 George W. Evans and Seppo Honkapohja, An Interview with Thomas J. Sargent, March 2005

1435 Helge Berger and Volker Nitsch, Zooming Out: The Trade Effect of the Euro in Historical Perspective, March 2005

1436 Marc-Andreas Muendler, Rational Information Choice in Financial Market Equilibrium, March 2005

1437 Martin Kolmar and Volker Meier, Intra-Generational Externalities and InterGenerational Transfers, March 2005

1438 M. Hashem Pesaran and Takashi Yamagata, Testing Slope Homogeneity in Large Panels, March 2005

1439 Gjermund Nese and Odd Rune Straume, Industry Concentration and Strategic Trade Policy in Successive Oligopoly, April 2005

1440 Tomer Blumkin and Efraim Sadka, A Case for Taxing Education, April 2005

1441 John Whalley, Globalization and Values, April 2005

1442 Denise L. Mauzerall, Babar Sultan, Namsoug Kim and David F. Bradford, Charging $\mathrm{NO}_{x}$ Emitters for Health Damages: An Exploratory Analysis, April 2005

1443 Britta Hamburg, Mathias Hoffmann and Joachim Keller, Consumption, Wealth and Business Cycles in Germany, April 2005

1444 Kohei Daido and Hideshi Itoh, The Pygmalion Effect: An Agency Model with Reference Dependent Preferences, April 2005

1445 John Whalley, Rationality, Irrationality and Economic Cognition, April 2005

1446 Henning Bohn, The Sustainability of Fiscal Policy in the United States, April 2005

1447 Torben M. Andersen, Is there a Role for an Active Fiscal Stabilization Policy? April 2005 